Annals of Warsaw University of Life Sciences - SGGW

Land Reclamation No 48 (4), 2016: 377-388

(Ann. Warsaw Univ. Life Sci. - SGGW, Land Reclam. 48 (4), 2016)

\title{
Application of Digital Elevation Model (DEM) for description of soil microtopography changes in laboratory experiments
}

\author{
TOMASZ STAŃCZYK, ANNA BARYŁA \\ Department of Environmental Improvement, Warsaw University of Life Sciences - SGGW
}

\begin{abstract}
Application of Digital Elevation Model (DEM) for description of soil microtopography changes in laboratory experiments. In the study we evaluated spatial and quantitative changes in soil surface microtopography to describe water erosion process under simulated rain with use of a non-contact optical 3D scanner. The experiment was conducted in two variants: with and without drainage layer. Two clay soils collected from farmlands from the catchment of lake Zgorzała (Warsaw) were investigated. Six tests of simulated rain were applied, with $55 \mathrm{~mm} \cdot \mathrm{h}^{-1}$. The surface roughness and microrelief were determined immediately after every $10 \mathrm{~min}$ of rainfall simulation by 3D scanner. The volume of surface and underground runoff as well as soil moisture were measured. The surface points coordinates obtained while scanning were interpolated using natural neighbour method and GIS software to generate Digital Elevation Models (DEM) with a $0.5 \mathrm{~mm}$ resolution. Two DEM-derived surface roughness indices: Random Roughness (RR) and Terrain Ruggedness Index (TRI) were used for microrelief description. Calculated values of both roughness factors have decreased with time under the influence of rainfall in all analyzed variants. During the sprinkling the moisture of all samples had been growing rapidly from air-dry state reaching values close to the maximum water capacity (37-48\% vol.) in 20-30 min. Simultaneously the intensity of surface runoff was increasing and cumulative runoff value was: $17-35 \%$ for variants with drainage and $72-83 \%$ for the variants without drainage, relative to cumulative rainfall. The observed soil surface elevation changes were associated with aggregates decomposition, erosion and sedimentation, and above all, with
\end{abstract}

a compaction of the soil, which was considered to be a dominant factor hindering the assessment of the erosion intensity of the of the scanned surface.

Key words: soil microrelief, soil erosion, rain simulation, roughness, DEM, 3D scanner

\section{INTRODUCTION}

Spatial differentiation of soil surface microtopography has a significant impact on the course of various processes underlying water erosion. The key indicator used to describe the diversity of the soil microtopography is surface roughness (Vidal Vázquez et al. 2005). Depending on roughness value there may be delay in the start of surface runoff by storing water in microdepressions, so high roughness is slowing runoff and its volume as well as the loss of soil through erosion (Allmaras et al. 1966, Onstad 1984, Hairsine et al. 1992, Darboux and Huang 2005, Bramorski et al. 2012).

The occurrence of the process of surface runoff and thus the sediment transport depends, among others, on the volume and intensity of rainfall, intensity of infiltration, surface slope. But still the main parameter determining the capacity of water storage on the soil surface 
is the roughness (Kamphorst et al. 2000, Alvarez-Mozos 2011). Knowledge of microrelief parameters and in particular the surface roughness is useful for modelling water erosion in physical models such as RUSLE (Renard et al. 1997), Erosion3D (Schmidt et al. 1999), LISEM (De Roo et al. 1996), WEPP (Flanagan and Nearing 1995). In RUSLE and WEPP models reduction of erosion occurs with increasing surface roughness. In the WEPP model increased surface roughness reduces the delivery of sediment from interrill erosion and increase the critical shear stress in rills.

Non-contact techniques, such as laser scanning (Huang et al. 1988, Helming et al. 1998, Arvidsson and Bölenius 2006) and photogrammetric methods (Jeschke 1990, Taconet and Ciarletti 2007) have proven to be effective in determination of changes in soil microrelief. Because of the time savings and precision of measurement they are increasingly popular in life and earth sciences. They allow to quickly obtain high resolution Digital Elevation Models (DEM) which are the basis of various spatial analysis commonly performed in Geographic Information Systems (GIS) among which geomorphological and hydrological analysis dominate (Brach and Chormański 2014, Falkowska et al. 2016).

In Poland, in erosion studies based on contactless methods, mainly terrestrial laser scanning was used. These studies were conducted in mountains (Dąbek et al. 2014) and uplands (Nie- miec et al. 2009) on larger areas but with a lower resolution. Application of non-laser, structured-light optical scanner for high-precision measurement of changes in soil microtopography is new in Polish studies, as well as, in foreign literature, where this type of scanner was used to obtain data for the validation of the roughness parameters derived from the terrestrial laser scanning (Milenković et al. 2015). The article presents the possibilities of using non-contact structured-light 3D optical scanner and DEM derived from scans to measure the temporal changes in soil surface height, assess the microrelief changes and determine the spatial distribution of erosion and sedimentation. The experiment was conducted under circumstances of rainfall simulation, what is commonly used method that allow to accelerate the examination of erosion processes (Helming et al. 1998, Römkens et al. 2002, Darboux and Huang 2005, Kukal and Sarkar 2011, Wawer et al. 2013).

An important aim of the study is also the assessment of changes in clay soils microrelief parameters. This type of soil is characteristic to the catchment of lake Zgorzała, where a strong erosion of arable land was observed in recent years.

\section{MATERIAL AND METHODS}

Measurements of soil microrelief were carried out on two clay soils (Table) taken from a depth of $0-30 \mathrm{~cm}$ from farmland under cultivation of vegetables from lake Zgorzała catchment located in 
TABLE. Physical characteristics of soil samples

\begin{tabular}{|l|c|c|c|c|c|}
\hline \multirow{2}{*}{ Sample } & \multicolumn{3}{|c|}{ Fraction (\%) } & \multirow{2}{*}{$\begin{array}{c}\text { Bulk density } \\
\left(\mathrm{kg} \cdot \mathrm{m}^{-3}\right)\end{array}$} & Soil texture \\
\cline { 2 - 5 } & $2-0.05 \mathrm{~mm}$ & $0.05-0.002 \mathrm{~mm}$ & $>0.002 \mathrm{~mm}$ & 1602 & sandy loam \\
\hline Soil 1 & 65 & 26 & 9 & 1628 & sandy loam \\
\hline Soil 2 & 73 & 21 & 6 & 9 \\
\hline
\end{tabular}

southern part of Warsaw. Collected soil samples were transported to the laboratory and prepared according to the method described by Kukal and Sarkar (2011). Firstly, the soil was dried to the optimum moisture content in order to stabilize the aggregates, and then the rock and plants parts was removed by sieving through a sieve with a mesh of $4 \mathrm{~mm}$ diameter to increase the homogeneity of the sample (Agassi and Bradford 1999, Tang et al. 2006).

Experiment (Fig. 1) was performed in a box with dimensions of $33.2 \times 19.5 \mathrm{~cm}$ with a constant slope $5 \%$. In the first setup version a $2 \mathrm{~cm}$ drainage layer consist of

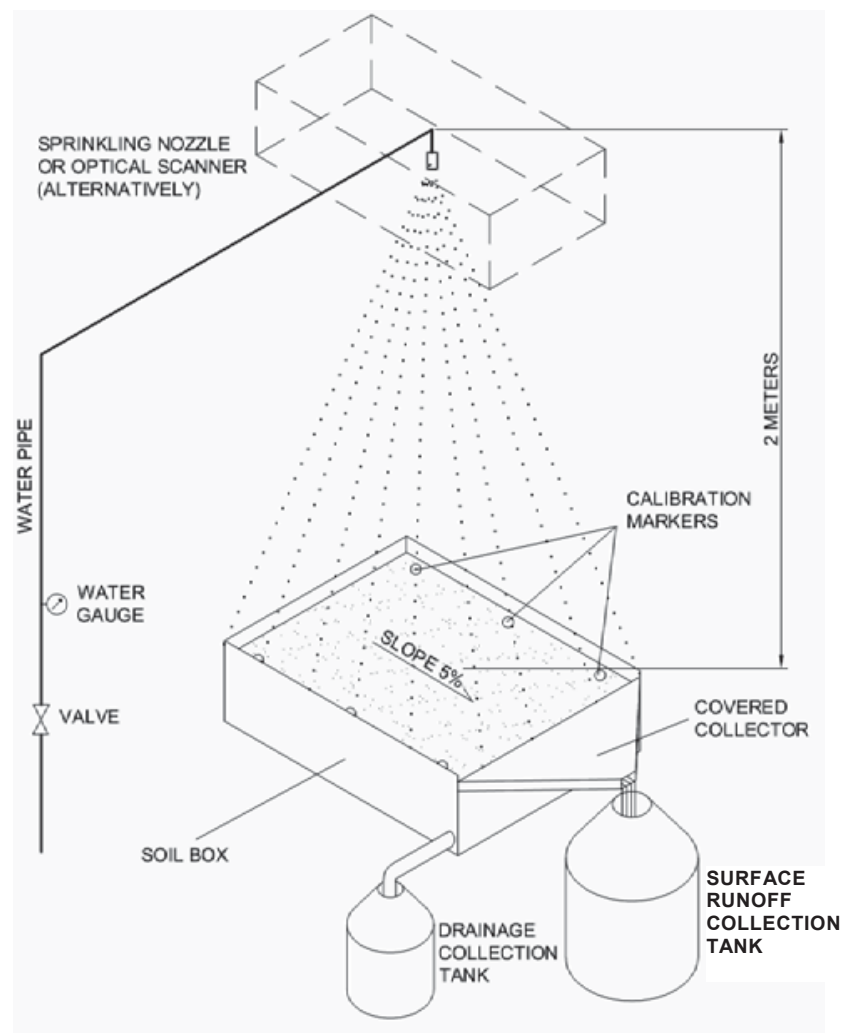

FIGURE 1. Scheme of experimental setup 
light expanded clay aggregate was laid on the bottom of the box. Next, it was covered with $10 \mathrm{~cm}$ layer of soil. Soil was compacted with use a $5 \mathrm{~kg}$ block of concrete. In the second version, the box was filled with $15 \mathrm{~cm}$ of soil with no drainage layer. Soil was compacted as before.

Precipitation was simulated using BEX 3/8 S24W nozzle suspended at a height of $2 \mathrm{~m}$ above the soil surface. Total sprinkling time was $60 \mathrm{~min}$ long and the rainfall intensity was kept at constant level of $55 \mathrm{~mm} \cdot \mathrm{h}^{-1}$. Soil moisture was measured with a laboratory TDR probe. Before the start of sprinkling and every $10 \mathrm{~min}$ of the experiment a scan was performed to determine changes in topography as well as volume of surface and subsurface outflow (only in the first setup) was measured. Sediment concentration was determined using the procedure of decantation and drying at $105^{\circ} \mathrm{C}$ for $24 \mathrm{~h}$ and then precisely weighed (Walling et al. 2001). Soil loss was calculated as the total dry mass of sediment loss from the box surface in individual time intervals.

The surface roughness and microrelief were determined immediately after every $10 \mathrm{~min}$ of rainfall simulation by non-contact ScanBright 3D structuredlight optical scanner, suspended over the scanned surface. Analyzed surface area was equal to $0.065 \mathrm{~m}^{2}$. This technique uses the line distortion effect as the light beam illuminating the surface of the object (the moiré effect). The obtained data $\left(93\right.$ points per $\mathrm{mm}^{2}$ ) were treated by removing the noise from point clouds with use the Mesh 3D software. Next, DEMs were interpolated with a resolution of $0.5 \mathrm{~mm}$ using natural neighbours method. Interpolation and further analyzes were performed with ArcGIS 10.3 software, which was also used to make maps of elevation differences and roughness of scanned surface as well as to calculate statistical characteristics of tested parameters and the volume of soil loss. Two methods for roughness estimation were used: Random Roughness (RR) and Terrain Ruggedness Index (TRI). Value of RR was calculated as the standard deviation of the $Z$ coordinate of all the cells constituting the DEM (Allmaras et al. 1966). Value of TRI was calculated according to the methodology proposed by Riley et al. (1999) using the TRI function implemented in the SAGA GIS software. This function calculates the TRI value for each cell based on the analysis of elevation ( $Z$ coordinate) of each of its eight neighbouring cells:

$$
T R I=\left[\sum\left(x_{i j}-x_{00}\right)^{2}\right]^{1 / 2}
$$

where:

$x_{i j}$ - elevation of each eight neighbouring cell to central cell $(0,0)$.

The radius of TRI calculation matched the maximum size of the soil aggregates and was equal 10 cells of DEM raster. Subsequently, mean TRI value was calculated from the whole DEM area. 


\section{RESULTS AND DISCUSSION}

As a result of the experiment, a series of DEMs representing the state of the soil surface at intervals of $10 \mathrm{~min}$, was obtained. Shaded relief maps of all four tested variants, presenting the soil surface state before and after rain simulation, are shown on Figure 2.

Soil samples prepared for sprinkling were levelled and did not have any patterns to simulate tilling. Therefore, the surface roughness was caused primarily by the presence of soil aggregates, which are clearly visible on shaded relief maps.
In the first minutes of the experiment aggregates undergone decomposition: their size was decreased but their fragmentation and quantity were increased. Typically, it was accompanied by a gradual surface roughness decay both expressed as a decline in the RR (Fig. 3) and TRI (Fig. 4).

A similar phenomenon, with respect to the ratio RR, described by Bauer et al. (2015). In two cases: Soil 1 with drainage (TRI) and Soil 2 without drainage (RR), the indices showed temporary slight increase in roughness of the soil in

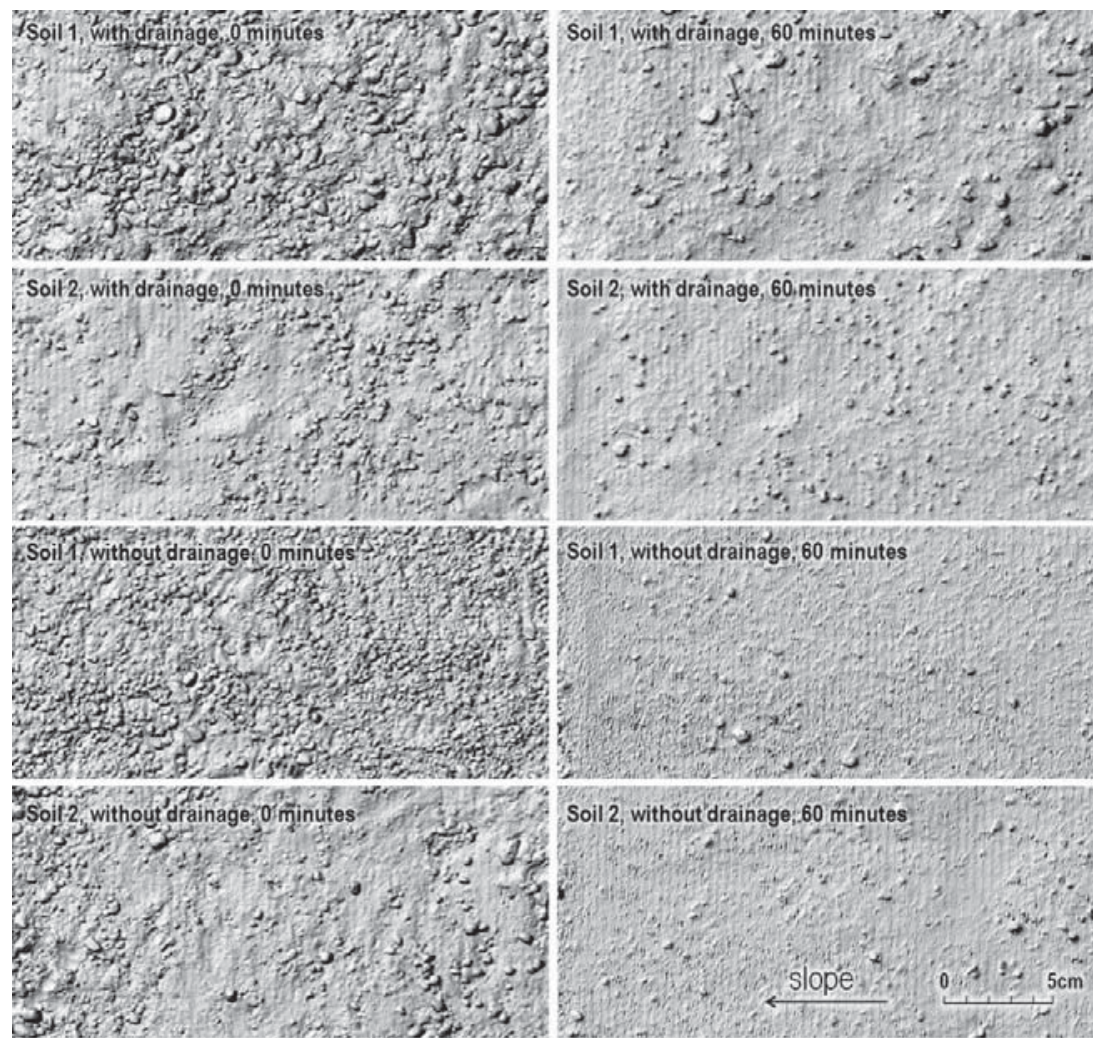

FIGURE 2. Shaded relief maps of soil sample surfaces before (left) and after rainfall simulation (right) 


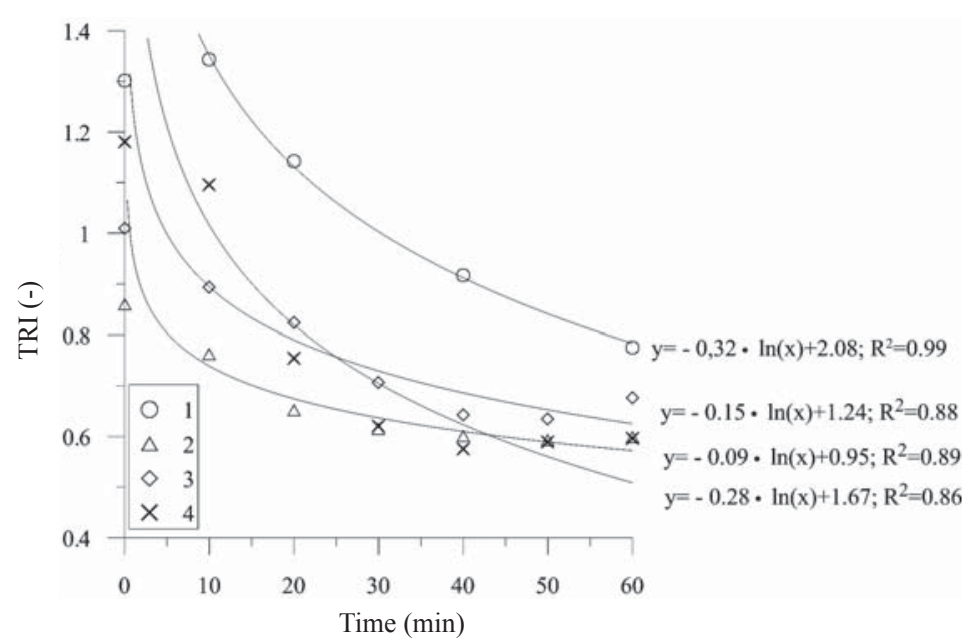

FIGURE 3. Changes of Terrain Ruggedness Index (TRI) in time: 1 - Soil 1 with drainage; 2 - Soil 2 with drainage; 3 - Soil 2 without drainage; 4 - Soil 1 without drainage

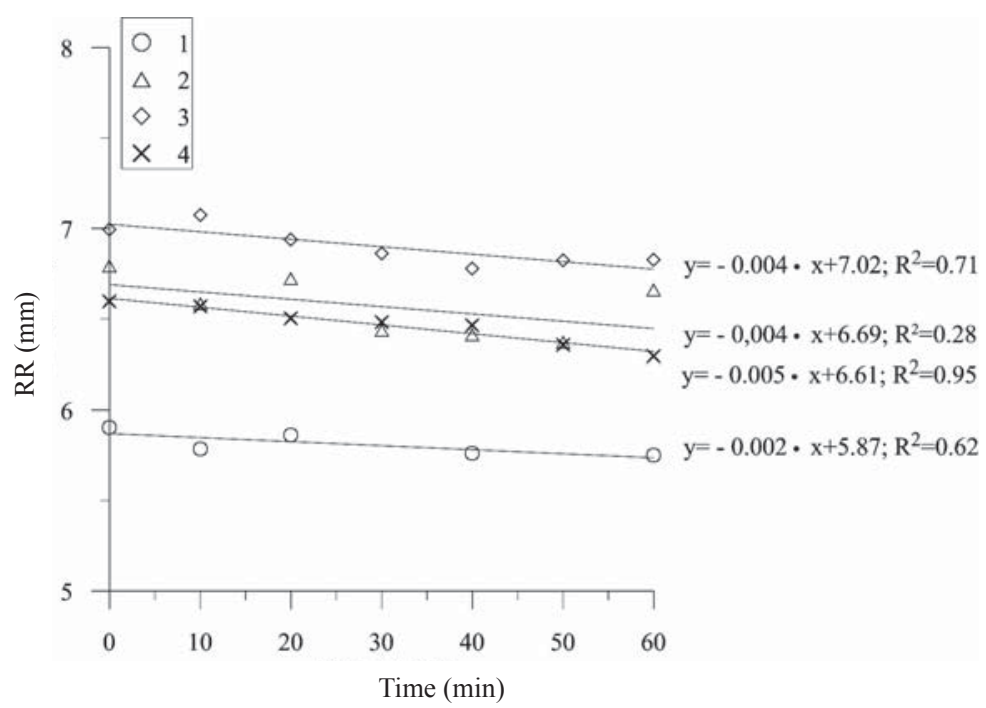

FIGURE 4. Changes of Random Roughness (RR) index in time: 1 - Soil 1 with drainage; 2 - Soil 2 with drainage; 3 - Soil 2 without drainage; 4 - Soil 1 without drainage

the first 10 min of the experiment, which the changes in microtopography of the can be attributed to disintegration of aggregates and sealing surface due to the impact energy of precipitation, which is the most important factor influencing soil (Wesemael et al. 1996).

Spatial diversity of surface roughness (TRI) is shown in Figure 5. Here we can see disappearance of local centres of in- 

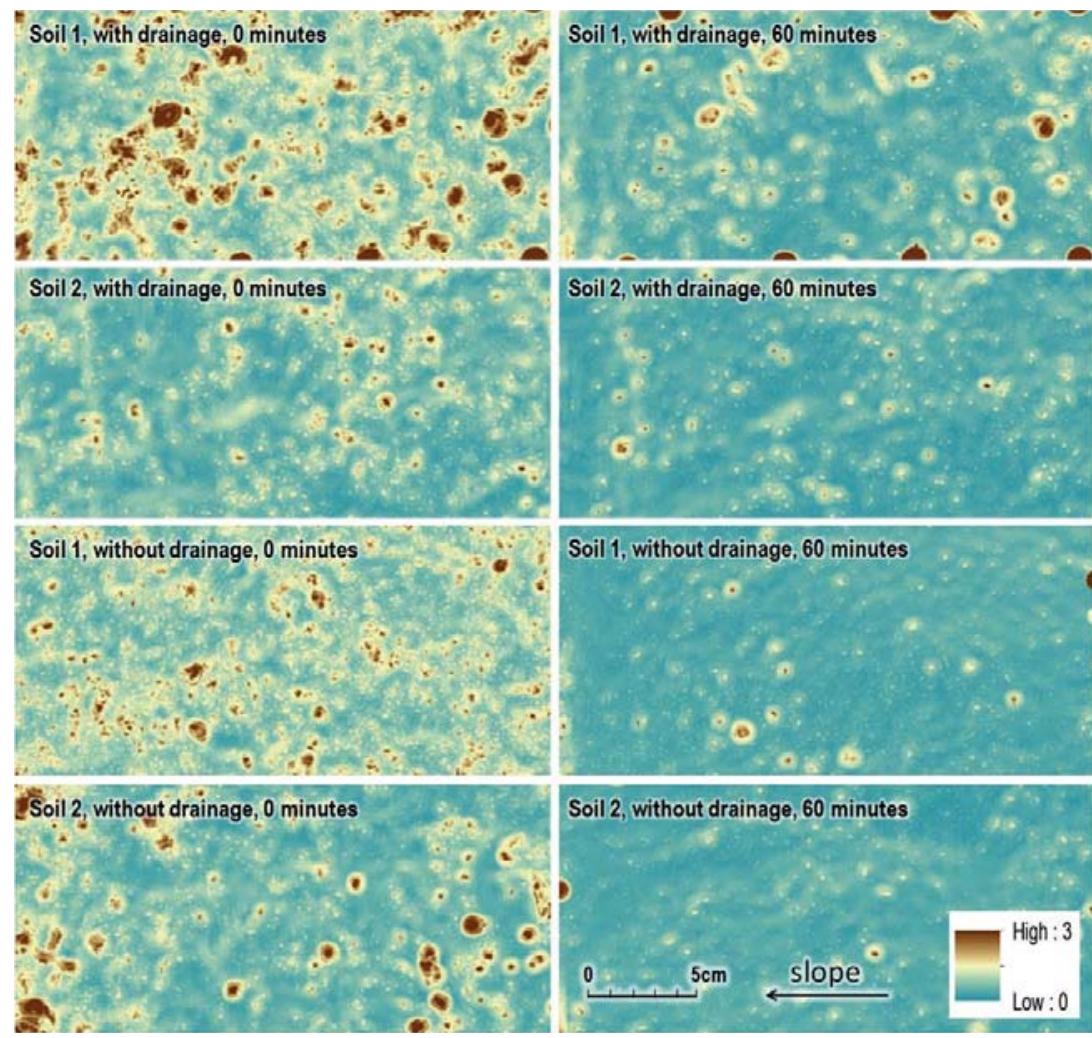

FIGURE 5. Terrain Ruggedness Index (TRI) maps of soil sample surfaces before (left) and after rainfall simulation (right)

creased roughness caused by the above-mentioned processes. The roughness attributable to aggregates is important in the initial phase of the runoff, when it can lead to a slowdown of water flowing down the slope. In studies conducted by other researchers the decrease of roughness factor as a function of the cumulative rainfall was also noticed (Magunda et al. 1997, Onstad et al. 1984, Linden and Van Doren 1986).

During the experiment, changes in soil moisture and volume of surface and subsurface runoff were recorded. Before the rain simulation samples were in air-dry state (4-6\% moisture). During the sprinkling the moisture of all samples had been growing rapidly and finally reached value close to the maximum water capacity (37-48\%). The rapid increase in soil saturation caused fast growth in the intensity of the surface runoff. The highest values of total surface runoff were observed in case of Soil 1 without drainage layer (Fig. 6), where the outflow had already appeared in the first minutes of sprinkling, while in other cases, the outflow had started only after ten minutes of simulation. Considerably smaller values of surface runoff 


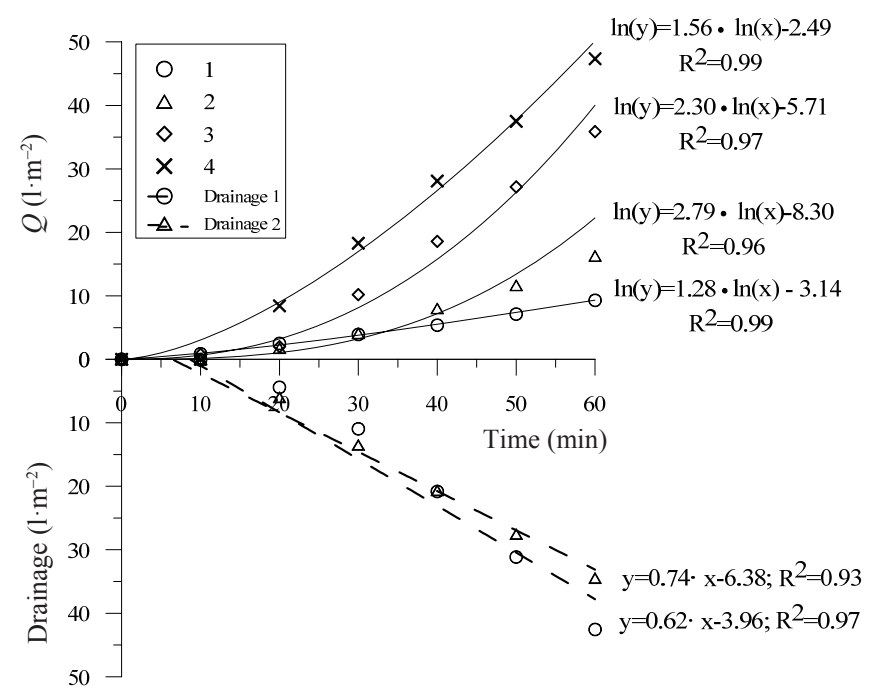

FIGURE 6. Cumulative surface $(Q)$ and drainage runoff in time: 1 - Soil 1 with drainage; 2 - Soil 2 with drainage; 3 - Soil 2 without drainage; 4 -Soil 1 without drainage

were noted during experiments conducted with a application of drainage layer. The total surface runoff in the variant with a drainage layer reached $17 \%$ (Soil 1) and $35 \%$ (Soil 2), and without drainage layer $72 \%$ (Soil 2) and $83 \%$ (Soil 1) of the total rainfall.

In the initial phase of the experiment there was observed a significant reduction in the average elevation of the soil surface (Fig. 7). Probably, this was caused by consolidation of the soil under the influence of rain and, to a lesser extent, by soil loss. This is suggested by the preliminary results of the analysis of the collected sediment quantity and other reports (Schmid et al. 2005). At the same time local depressions located near the runoff collector were filled with sediment (Fig. 8). In the case of Soil 2 with drainage the decrease in elevation was the most distinct. Unfortunately, it could be caused by insufficient compaction of the soil before the experiment.

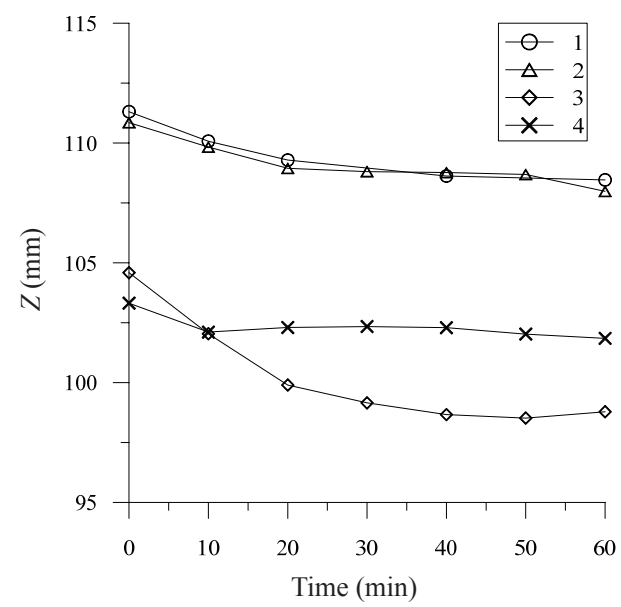

FIGURE 7. Changes of mean soil surface elevation in time: 1 - Soil 1 with drainage; 2 - Soil 2 with drainage; 3 - Soil 2 without drainage; 4 - Soil 1 without drainage 

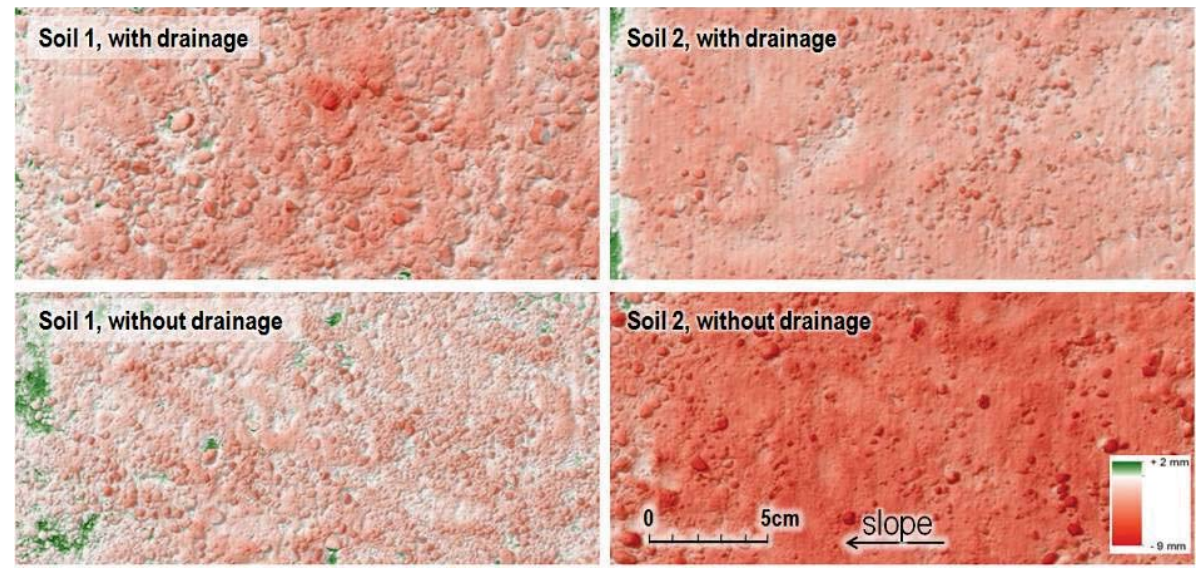

FIGURE 8. Maps of soil surface elevation changes before and after the rainfall simulation

\section{CONCLUSIONS}

The study showed a decrease in roughness indices with time under the influence of rainfall. Reduction of roughness values can be attributed to degradation of aggregates and sealing surface due to the impact energy of precipitation, which is consistent with the results of other authors. It can be said that among the two methods used to determine changes in surface roughness the TRI method was more sensitive than RR. Surveys of surface microtopography, for example maps of TRI or maps of surface elevation changes, not only allow to assess erosion risks, but also to determine the spatial distribution of erosion and sedimentation processes effects and to trace of its changes in time.

The accuracy of used scanner seemed to be sufficient in detecting soil surface elevation changes in the below millimetre range, as long as congruence of the subsequent scans can be achieved with high precision. However, in simple volume balances other relief-forming processes of soils, like compaction by rain can mask soil losses by erosion. It could be the cause of differences in the estimated soil loss between the values, that can be determined based on the average decrease in surface elevation of the subsequent DEMs, and amounts of sediment in collected surface runoff. Presumably preparation of the sample by single or multiple pre-sprinkling would help to reduce the effect of compaction during the experiment.

The results showed that the proposed approach can quickly and precisely provide data suitable for quantitatively determine soil microtopography changes.

\section{Acknowledgment}

The equipment supplied by the Irrigation and Drainage Lab of the WULS-SGGW Water Centre was used to conduct presented investigations. 


\section{REFERENCES}

AGASSI M., BRADFORD J.M. 1999: Methodologies for interrill soil erosion studies. Soil Till. Res. 49 (4), 277-287.

ALLMARAS R.R., BURWELL R.E., LARSON W.E., HOLT R.F. 1966: Total porosity and random roughness of the interrow zone as influenced by tillage. 7th edn. USDA Conserv. Res. Rep., U.S. Gov. Print. Office, Washington DC.

ALVAREZ-MOZOS J., MIGUEL ANGEL C., GIMENEZ R., CASALI J., LEIBAR U. 2011: Implications of scale, slope, tillage operation and direction in the estimation of surface depression storage. Soil Till. Res. 111, 142-153.

ARVIDSSON J., BÖLENIUS E. 2006: Effects of soil water content during primary tillage - laser measurements of soil surface changes. Soil Till. Res. 90 (1-2), 222-229.

BAUER T., STRAUSS P., GRIMS M., KAMPTNER E., MANSBERGER R., SPIEGEL H. 2015: Long-term agricultural management effects on surface roughness and consolidation of soils. Soil Till. Res. 151, 28-38.

BRACH M., CHORMAŃSKI J. 2014: Terrestrial Laser Scanning (TLS) as a detection method of the natural river valley microtopography - case study of the Upper Biebrza. Ann. Warsaw Univ. Life Sci. - SGGW, Land Reclam. 46 (4), 276-278.

BRAMORSKI J., De MARIA I.C., CRESTANA S. 2012: Relations between soil surface roughness, tortuosity, tillage treatments, rainfall intensity and soil and water losses from a red yellow latosol. Rev. Bras. Ciênc. Solo. 36 (4), 1291-1298.

DARBOUX F., HUANG C. 2005: Does soil surface roughness increase or decrease water and particle transfers? Soil Sci. Soc. Am. J. 69, 748-756.

DĄBEK P., ŻMUDA R., ĆMIELEWSKI B., SZCZEPAŃSKI J. 2014: Analysis of water erosion processes using terrestrial laser scanning. Acta Geodyn. Geomater. 11, 1 (173), $45-52$.

De ROO A.P.J., WESSELING C.G., RITSEMA C.J. 1996: LISEM: a single event physically- -based hydrologic and soil erosion model for drainage basins: I. Theory, input and output. Hydrol. Process. 10, 1107-1117.

FALKOWSKA E., FALKOWSKI T., BRACH M. 2016: The use of digital elevation model (DTM) in the facies differentiation analysis of flood sediments of the Vistula river between Basonia and Solec upon Vistula and its importance for the concentration of heavy metals. Sci. Rev. Eng. Env. Sci. 25 (3), 311-322 [in Polish].

FLANAGAN D.C., NEARING M.A. 1995: USDA - Water Erosion Prediction Project. Hillslope profile and watershed model documentation. Nat. Soil Erosion Research Lab. In: Lafayette, Indiana 47907, USA. USDA ARS. NSERL Report 10, 1196-47097.

HAIRSINE P.B., MORAN C.J., ROSE C.W. 1992: Recent developments regarding the influence of soil surface characteristics on overland flow and erosion. Aust. J. Soil Res. 30, 249-264.

HELMING K., RÖMKENS M.J.M., PRASAD S.N. 1998: Surface roughness related processes of runoff and soil loss: a flume study. Soil Sci. Soc. Am. J. 62 (1), 243-250.

HUANG C., WHITE I., THWAITE E.G., BENDELI A. 1988: A noncontact laser system for measuring soil surface topography. Soil Sci. Soc. Am. J. 52 (2), 350-355.

JESCHKE W. 1990: Digital close-range photogrammetry for surface measurement. Int. Arch. Photogramm. and Remote Sens. 28 (5), 1058-1065.

KAMPHORST E.C., JETTEN V., GUÉRIF J., PITKÄNEN J., IVERSEN B.V., DOUGLAS J.T., PAZ A. 2000: Predicting depressional storage from soil surface roughness. Soil Sci. Soc. Am. J. 64, 1749-1758.

KUKAL S.S., SARKAR M. 2011: Laboratory simulation studies on splash erosion and crusting in relation to surface roughness and raindrop size. J. Indian Soc. Soil Sci. 59 (1), 87-93.

MILENKOVIĆ M., PFEIFER N., GLIRA P. 2015: Applying terrestrial laser scanning for soil surface roughness assessment. Remote Sens. 7 (2), 2007-2045. 
NIEMIEC M., JÓŹKÓW G., BORKOWSKI A. 2009: Monitoring land surface changes caused by soil water erosion with terrestrial laser scanning. Arch. Fotogram. Kartogr. $i$ Teledet. 20, 333-342 [in Polish].

ONSTAD C.A. 1984: Depressional storage on tilled soil surfaces. Trans. Am. Soc. Agric. Eng. 27 (3), 729-732.

RENARD K.G., FOSTER G.R., WESSIES G.A., MCCOOL D.K., YODER D.C. 1997: Predicting soil erosion by water: a guide to conservation planning with the Revised Universal Soil Loss Equation (RUSLE). Agricultural Handbook 703, USDA-ARS.

RILEY S.J., DeGLORIA S.D., ELLIOT R. 1999: A terrain ruggedness index that quantifies topographic heterogeneity. Interm. J. Sci. 5 (1-4), 23-27.

RÖMKENS M.J., HELMING K., PRASAD S. N. 2002: Soil erosion under different rainfall intensities, surface roughness, and soil water regimes. Catena 46 (2), 103-123.

SCHMID T., SCHACK-KIRCHNER H., HILDEBRAND E. 2005: A case study of terrestrial laser scanning in erosion research: Calculation of roughness and volume balance at a logged forest site. Inter. Arch. Photogramm. Remote Sens. Spatial Infor. Sci. 36, 114-118.

SCHMIDT J., Von WERNER M., MICHAEL A., 1999. Application of the EROSION 3D model to the CATSOP watershed, The Netherlands. Catena 37, 449-456.

TACONET O., CIARLETTI V. 2007: Estimating soil roughness indices on ridge-and-furrow surface using stereo photogrammetry. Soil Till. Res. 93 (1), 64-76.

TANG Z., LEI T., YU J., SHAINBERG I., MAMEDOV A.I., BEN-HUR M., LEVY G.J. 2006: Runoff and interrill erosion in sodic soils treated with dry PAM and phosphogypsum. Soil Sci. Soc. Am. J. 70 (2), 679-690.

VIDAL VÁZQUEZ E., MIRANDA J.G.V., ALVES M.C., PAZ GONZÁLEZ A. 2006: Effect of tillage on fractal indices describing soil surface microrelief of Brazilian Alfisol. Geoderma 134, 3006-3317.

WALLING D.E., COLLINS A.L., SICHINGABULA H.M., LEEKS G.J.L. 2001. Integrated assessment of catchment suspended sediment budgets: a Zambian example. Land Degrad. Develop. 12, 387-415.

WAWER R., NOWOCIEŃ E., PODOLSKI B. 2013: Sediment uptake rates under extreme rainfall in controlled conditions. J. Food Agric. Environ. 11 (1), 1089-1093.

Streszczenie: Wykorzystanie numerycznego modelu terenu (NMT) do opisu zmian mikrotopografii gleb $w$ badaniach laboratoryjnych. W pracy oceniono przestrzenne i ilościowe zmiany mikrotopografii gleby umożliwiające opis przebiegu procesu erozji wodnej w warunkach symulowanego deszczu na podstawie analizy powierzchni bezstykowym optycznym skanerem 3D. Doświadczenie przeprowadzono $\mathrm{w}$ dwóch wariantach bez warstwy drenażowej i z nią na dwóch glebach gliniastych pobranych z pól uprawnych ze zlewni jeziora Zgorzała (Warszawa). Dla każdego wariantu przeprowadzono sześć testów laboratoryjnych $\mathrm{w}$ warunkach symulowanego opadu o stałym natężeniu równym $55 \mathrm{~mm} \cdot \mathrm{h}^{-1}$. Po każdych 10 min trwania opadu wykonywano skanowanie powierzchni gleby. Mierzono też objętość powierzchniowego i podziemnego odpływu oraz wilgotność gleby. Z uzyskanych współrzędnych punktów w programie ArcGIS 10.3 interpolowano metodą natural neighbour numeryczne modele terenu (NMT) o rozdzielczości $0,5 \mathrm{~mm}$. $\mathrm{W}$ ocenie mikroreliefu wykorzystano indeksy szorstkości powierzchni obliczone na podstawie poszczególnych NMT metodami Random Roughness (RR) i Terrain Ruggedness Index (TRI). Wartości obu wskaźników szorstkości zmniejszały się z czasem pod wpływem opadów deszczu w każdym z analizowanych wariantów. Wilgotność gleby zwiększała się od stanu powietrznie suchego do maksymalnej pojemności wodnej w ciągu 20-30 min. Wraz z nią rosła intensywność odpływu powierzchniowego, a jego sumaryczna wartość względem sumy opadów zmieściła się w zakresach: $17-35 \%$ dla wariantów z drenażem i $72-83 \%$ dla wariantów bez drenażu. Zaobserwowane zmiany wysokości powierzchni gleby były związane $\mathrm{z}$ rozbijaniem agregatów, erozją i sedymentacją oraz przede wszystkim z osiadaniem gleby, które uznano za czynnik dominujący, utrudniający ocenę intensywności erozji skanowanej powierzchni. 
MS received October 2016

\section{Authors' address:}

Tomasz Stańczyk, Anna Baryła

Katedra Kształtowania Środowiska

Wydział Budownictwa i Inżynierii Środowiska

SGGW

ul. Nowoursynowska 166, 02-787 Warszawa

Poland

e-mail: tomasz_stanczyk@sggw.pl

anna_baryla@sggw.pl 